\title{
Quantitative Assay Method for Starch Branching Enzyme with Bicinchoninic Acid by Measuring the Reducing Terminals of Glucans
}

\author{
(Received October 2, 2008; Accepted April 30, 2009) \\ Yoshinori Utsumi, ${ }^{1}$ Mayumi Yoshida, ${ }^{1}$ Perigio B. Francisco, Jr., ${ }^{1}$ Takayuki Sawada, ${ }^{1}$ \\ Shinichi Kitamura ${ }^{2}$ and Yasunori Nakamura, \\ ${ }^{1}$ Faculty of Bioresource Sciences, Akita Prefectural University \\ (241-438, Kaidobata-Nishi, Nakano, Shimoshinjo, Akita 010-0195, Japan) \\ ${ }^{2}$ Graduate School of Life and Environmental Sciences, Osaka Prefecture University \\ (1-1, Gakuen-cho, Naka-ku, Sakai 599-8531, Japan)
}

\begin{abstract}
A reliable quantitative assay method for starch branching enzyme (BE) remains to be established whereas it has been required to characterize BE towards understanding the regulatory mechanism for the synthesis of starch in plant tissues. We describe a new quantitative assay method for BE activities with maltooligosaccharides, amylose and amylopectin as substrates by using bicinchoninic acid (BCA) for measuring directly the reducing terminals of linear glucans formed after debranching the reaction products. The BCA method not only can be performed by simple procedures and easy handling with the use of cheap toxic-free reagents, but also shows highly color-stable properties after the treatment of the reaction mixture with the color-yielding reagents compared with the modified Park-Johnson method (Carbohydr. Res., 94, 205-213 (1981)). The intensity and the spectrum of the purple color generated in the treated assay mixture are maintained in sugars and glucans in the range of glucose and amylose with degree of polymerization up to at least 1658. The BCA method can be also applied for characterization of $\mathrm{BE}$ when amylopectin is used as glucan substrate. In this paper we report this efficient, reproducible and quantitative BCA method by showing some experimental results obtained in an attempt to determine the kinetic parameters of BEIIb from rice endosperm.
\end{abstract}

Key words: amylopectin, bicinchoninic acid, starch branching enzyme, starch

Starch is a glucose polymer with two $\alpha$-glucosidic linkages, and linearly linked $\alpha-1,4$-glucosidic chains are branched by $\alpha-1,6$-glucosidic linkages. Starch is composed of linear or fewly branched amylose and highly branched amylopectin. Amylopectin has a distinct highly ordered structure called "tandem-cluster structure", in which most side chains are arranged in parallel and pairs of neighboring chains form double helices ${ }^{1)}$ when linear portions of these chains reach the length equivalent to degree of polymerization (DP) $\geq 10 .^{2-5}$ The formation of double helices in the amylopectin cluster dramatically induces its hydrophobicity and crystallinity. These specific features of amylopectin fine structure are enabled by the localization of position of branches in the cluster. ${ }^{6}$ The starch synthesis system has developed during the process of evolution of plants, ${ }^{6,7)}$ and key enzymes involved in the construction of amylopectin tandem-cluster structure have differentiated into multiple isozymes with distinct functions whereas in glycogen synthesizing organisms such as bacteria and animals no such functional differentiations in glycogen synthesis enzymes have occurred. ${ }^{8,9)}$

Starch branching enzyme (BE) plays an important part in the formation of branches in amylopectin molecules. Green plants are known to have two types of $\mathrm{BE}$ isozymes, BEI and BEII. In addition, BEII is further differentiated into BEIIa and BEIIb isoforms in cereals al-

* Corresponding author (Tel. +81-18-872-1652, Fax. +81-18-8721681, E-mail: nakayn@akita-pu.ac.jp). though BEIIb is usually specifically expressed in endosperm while BEIIa is ubiquitously present in every tissue. ${ }^{10-13)}$ Our biochemical studies on three mutants of rice which are defective in BEI, BEIIa and BEIIb, respectively, strongly suggest that the role of BEIlb is most specific in synthesizing branches located on the basal portion of the crystal zone (referred to as the crystal lamellae) of the cluster because BEI and BEIIa can hardly complement its role in its absence. ${ }^{8,14)}$ On the other hand, BEI plays an important part in forming branches which are positioned at the basal part of the cluster in the less crystalline zone (referred to as the amorphous lamellae), and those which link the clusters, but its role can be largely complemented by BEIIb and BEIIa in the BEI mutant. ${ }^{15)}$ Although the activity of BEIIa accounts for about $20 \%$ of the total BE activity in rice endosperm, the specificity of its function must be poor because no significant changes in the structure of amylopectin or the physicochemical properties of starch granules are found in the BEIIa mutant (Nishi et al., unpublished data).

In vitro studies using purified $\mathrm{BE}$ isozymes revealed that BEI and BEII differ in terms of specificity for glucans, amylose or amylopectin, and the length of glucan chains transferred; BEI prefers to attack amylose to amlopectin and preferentially transfers various glucan chains with DP values greater than 6, whereas BEII prefers to use amylopectin to amylose, and preferentially transfers short chains with DP6 in addition to DP7. ${ }^{16-23)}$

In past $\mathrm{BE}$ investigations, the activity has been assayed 
mainly using three methods ${ }^{18,24}$; Firstly, the phosphorylase a stimulation assay, which is based on the extent of stimulation of the activity of rabbit muscle phosphorylase a by $\mathrm{BE},{ }^{18-24)}$ secondly, the iodine stain assay, which is based on monitoring the decrease in absorbance of the glucan-iodine complex catalyzed with the addition of $\mathrm{BE},{ }^{24,25}$ and thirdly, the branching linkage assay (BL assay) based on the direct measurement of number of branched linkages introduced in glucan substrate by BE. ${ }^{17)}$ Although the phosphorylase a stimulation assay and the iodine stain assay have been most conventionally used, these methods are basically non-quantitative. The BL assay is essentially the quantitative method for determining $\mathrm{BE}$ activity. However, it should be noted that the $\mathrm{BE}$ preparation used for assay must be free from glucanhydrolyzing enzymes such as amylases and starch debranching enzymes.

Up to now two methods have been applied to the BL assay. One is referred to as the Somogyi-Nelson method, in which the reducing power of glucans is measured by molybdenum-blue. ${ }^{26,27)}$ The Somogyi-Nelson method is known to be inadequately sensitive. ${ }^{1726)}$ The second method is called the modified Park-Johnson method, ${ }^{28)}$ where the reducing glucan terminals are determined by ferric-ferrocyanide. Although the amount of ferricferrocyanide is equal to the reducing power of glucans of DP up to $40,{ }^{28)}$ it is known that the ferric-ferrocyanide tends easily to lose its solubility in aqueous solution, and hence the measurement of absorbance of the assay solution should be performed within 20 min after the addition of color-yielding reagent. Takeda et al . (1993) ${ }^{17)}$ applied the modified Park-Johnson method to characterize the maize BE. However, it has disadvantages in the instability of the color properties because the intensity of the absorption color decreases with time and therefore one should measure the exact time (for example $20 \mathrm{~min}$ ) after the addition of the reagent. ${ }^{28)}$ On the other hand, Hanashiro et al . $(2003)^{29)}$ developed a method for analysis of BE enzymatic reaction products by fluorescent labeling of reducing terminals of branched chains after the treatment of Pseudomonas isoamylase with 2-aminopyridine. The method is advantageous to the analysis of chain-length distribution of $\mathrm{BE}$ reaction products whereas it is less convenient to apply for the kinetic studies of BE due to some difficulties in quantifying precisely and reproducibly the amounts of reducing terminals produced by the $\mathrm{BE}$ reaction.

The bicinchoninic acid (BCA) method as well as the modified Park-Johnson method and the Somogyi-Nelson method is based on the reduction of $\mathrm{Cu}$ (II) to $\mathrm{Cu}$ (I). The BCA method has been used to measure the reducing power in sugars by the amount of copper bicinchoninate, which is formed from $\mathrm{Cu}(\mathrm{I})$ and bicinchoninate at alkali $\mathrm{pH}$ under high temperature. This method does not require toxic chemicals and needs only one reagent for detection, whereas in both the Somogyi-Nelson method and the modified Park-Johnson method three and four reagents are needed to make the reducing power visible, respectively. ${ }^{30-32)}$ The copper-bicinchoninate can detect the reducing power of hexoses, pentoses, hexuronic acids and oligosaccharides derived from starch, polygalacturonic acid and chitin. ${ }^{33,34)}$ Although the BCA method has been used to screen expression libraries for carbohydrases ${ }^{34)}$ and kinetic characterization of starch debranching enzyme $\mathrm{e}^{35,36)}$ and cellulase, ${ }^{37}$ no publication has been found using the method for assay of BE.

This report describes basic properties of the BCA method by which the amount of branched linkages formed by $\mathrm{BE}$ reaction is determined. It was found that the BCA method exhibits high color stability and shows the same reducing power ranging from glucose to linear amylose with DP $n$ values at least within 1658 . The present study shows experimental results which were obtained in an attempt to examine whether the BCA method is useful for quantitative measurement of BE activity using amylose or amylopectin as glucan substrate, and this can be applied to characterize $\mathrm{BE}$ isozymes by determining their kinetic parameters.

\section{MATERIALS AND METHODS}

Materials. Five amylose samples, AS-7, AS-55, AS290, AS-820 and AS-1160, were enzymatically synthesized by a previously reported method using potato phosphorylase (EC 2.4.1.1.). ${ }^{38-40)}$ The number- and weightaverage molecular weights $\left(M_{\mathrm{n}}, M_{\mathrm{w}}\right)$ and molecular weight distributions were evaluated by high-performance gel permeation chromatography (GPC) using a low-angle laser-light-scattering photometer (LALLS; LS8000; Tosoh Corporation, Japan) and a differential refractometer (RI; RI-8011; Tosoh Corporation) as detectors. Based on the $M_{\mathrm{n}}$ values, the number-average degree of polymerization (DPn) can be calculated as 6510 (AS-1160), 4820 (AS820), 1658 (AS-290), 317 (AS-55) or 34 (AS-7), respectively. The amylose was dissolved in $0.25 \mathrm{M}$ aqueous $\mathrm{CH}_{3}$ COOK at a concentration of $1 \%$ and injected into GPC columns that were thermostatically controlled at $55^{\circ} \mathrm{C}$. Three sequentially connected columns of G2000PW, G 3000PW and G5000PW (Tosoh Corporation, Japan) were used for AS-7 and AS-55. For high molecular weight amylase, A-290, A-820 and A-1160, a column combination of G3000PW, G5000PW and G6000PW was used. The flow rate was $0.7 \mathrm{~mL} / \mathrm{min}$ for both column systems. The LALLS photometer used in this system measures scattering intensity at $\theta=5^{\circ}$, where the correction for angular dependence to $\theta=0$ can be ignored. The RI and LALLS signals at each point of the chromatogram were analyzed by a software package provided by Tosoh Corporation, to determine $M_{\mathrm{w}}, M_{\mathrm{n}}$ and molecular weight distribution curves. The amylopectin from rice seeds from a BEIIb-deficient amylose-extender (ae) mutant line EM $10^{15)}$ was removed from amylose which was precipitated with 1-butanol and isoamylalcohol according to the method of Takeda et al. (1986). ${ }^{41)}$ To remove the lower $M_{\mathrm{w}}$ glucans in the AS-1160 and AS-820 preparations, 20 $\mathrm{mg}$ of these preparations were dissolved in $1 \mathrm{~mL}$ of $100 \%$ dimethylsulfoxide at $80^{\circ} \mathrm{C}$ and added to $8 \mathrm{~mL}$ of distilled water. The dissolved amylose was precipitated by adding $1 \mathrm{~mL}$ of $100 \%$ 1-butanol and $100 \mu \mathrm{L}$ of $5 \mathrm{M} \mathrm{NaCl}$, and centrifuged at $10,000 \times g$ for $20 \mathrm{~min}$. The procedure was repeated 4 times. The finally resulting precipitate was dried by washing with acetone and diethylether, and stored at $-30^{\circ} \mathrm{C}$ until use. 


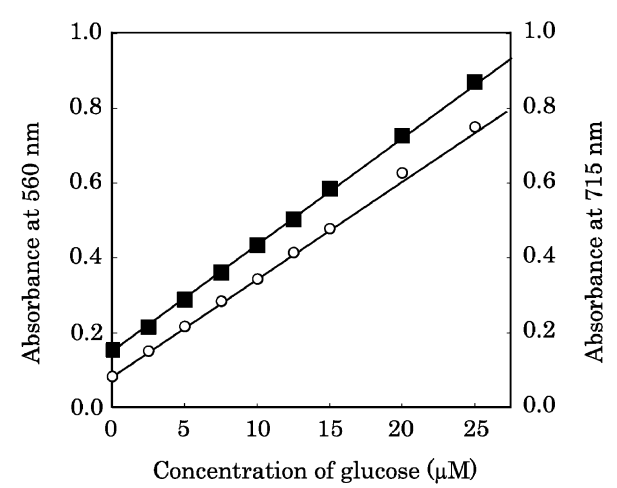

Fig. 1. The relationship between glucose concentration and absorbance of the assay mixture measured by the BCA method (560 nm, open circle) or the modified Park-Johnson method (715 nm, closed square).

The absorbance was determined using a microplate spectrophotometer (Bio-Rad) after $150 \mu \mathrm{L}$ each of the assay mixture was taken into a hole of the microplate.

Determination of reducing power by the BCA method. Solution A consisted of $97.1 \mathrm{mg}$ of disodium 2,2'bicinchoninate (BCA), $3.2 \mathrm{~g}$ of sodium carbonate monohydrate and $1.2 \mathrm{~g}$ of sodium bicarbonate in a total volume of $50 \mathrm{~mL}$. Solution B consisted of $62 \mathrm{mg}$ of copper sulfate pentahydrate and $63 \mathrm{mg}$ of L-serine in a total volume of $50 \mathrm{~mL}$. The working reagent was freshly prepared by mixing equal volumes of Solutions $\mathrm{A}$ and $\mathrm{B}{ }^{32}{ }^{32}$ Two hundred and twenty-five $\mu \mathrm{L}$ of the carbohydrate sample were added to $225 \mu \mathrm{L}$ of the working reagent in an Eppendorf tube, and the mixture was incubated at $80^{\circ} \mathrm{C}$ for $40 \mathrm{~min}$ in a water bath. After the incubation, the assay mixture was then cooled to room temperature and stood for $10 \mathrm{~min}$. An aliquot $(150 \mu \mathrm{L})$ of the BCA treated sample was taken and its absorbance at $560 \mathrm{~nm}$ was measured by using microplate spectrophotometer (Bio-Rad). The absorbance at $560 \mathrm{~nm}$ was found to be proportional to the concentration of maltose or glucose in the range of 0 to at least $25 \mu \mathrm{M}$ of the assay mixture.

Determination of reducing power by the modified Park-Johnson method. The modified Park-Johnson method was performed according to the method described by Hizukuri et al. (1981). ${ }^{28)}$ Solution C consisted of 65 $\mathrm{mg}$ of potassium cyanide, $0.48 \mathrm{~g}$ of sodium carbonate monohydrate and $0.92 \mathrm{~g}$ of sodium bicarbonate in a total volume of $100 \mathrm{~mL}$. Solution D consisted of $0.1 \mathrm{~g}$ of potassium ferricyanide in a total volume of $100 \mathrm{~mL}$. Solution $\mathrm{E}$ consisted of $1.5 \mathrm{~g}$ of ferric-ammonium sulfate monohydrate and $1.33 \mathrm{~mL}$ of concentrated sulfuric acid in a total volume of $500 \mathrm{~mL}$. One hundred microlitters of the carbohydrate sample was mixed with $100 \mu \mathrm{L}$ of the solution prepared by mixing equal volumes of Solutions C and $\mathrm{D}$, and the mixture was heated at $100^{\circ} \mathrm{C}$ for $20 \mathrm{~min}$ in a water bath. After cooling with water at room temperature for $10 \mathrm{~min}$, the mixture was supplemented with 250 $\mu \mathrm{L}$ of Solution E. The assay mixture thus treated stood exactly for $20 \mathrm{~min}$ at room temperature, and the absorbance of the mixture was immediately measured at 715 $\mathrm{nm}$. The absorbance at $715 \mathrm{~nm}$ increased with increases in concentrations of maltose or glucose in the range of 0 to at least $25 \mu \mathrm{M}$ in the assay mixture.

Construction of expression vector in Escherichia coli for expression of rice BEIIb gene. The cDNA encoding rice BEIIb (OsBEIlb) was isolated by one-step polymerase chain-reaction (PCR) with mRNA (QIAGEN) prepared from endosperm of japonica-type rice cultivar Kinmaze. The DNA fragment encoding OsBEIIb mature protein was generated by PCR using a forward primer containing HpaI 5'-gttaacggcggcgggcgcgtcaggggaggtg-3' and a reverse primer containing SalI 5'-gtcgactcattccgctggagcatagac3'. The PCR product was treated with restricted enzymes (HpaI-Sal I) and assembled into an expression vector $\mathrm{pET}$ $44 \mathrm{~b}$ (Novagen ${ }^{\circledR}$ ) at the PshAI-Sal I sites.

Induction of recombinant OSBE (rOsBEIIb). The constructed plasmid including the OsBEIIb cDNA was incorporated into Escherichia coli AD494 (DE3) pLysS strain $\left(\right.$ Novagen ${ }^{\circledR}$ ). The transformed cells were incubated with $30 \mathrm{~mL}$ of LB medium containing $100 \mu \mathrm{g} / \mathrm{mL}$ of ampicillin, $34 \mu \mathrm{g} / \mathrm{mL}$ of chloramphenicol and $15 \mu \mathrm{g} / \mathrm{mL}$ of kanamycin at $37^{\circ} \mathrm{C}$ for overnight. Thirty milliliters of the culture solution was diluted with $3000 \mathrm{~mL}$ of LB medium containing $100 \mu \mathrm{g} / \mathrm{mL}$ of ampicillin, $34 \mu \mathrm{g} / \mathrm{mL}$ of chloramphenicol and $15 \mu \mathrm{g} / \mathrm{mL}$ of kanamycin and the mixed culture was incubated at $37^{\circ} \mathrm{C}$. When the optical density at $600 \mathrm{~nm}$ of the cell culture reached approximately 0.4 to 0.5 , the cells containing pET44b-OsBEIIb were preincubated at $15^{\circ} \mathrm{C}$ for $30 \mathrm{~min}$, and then the expression of OsBEIIb protein was induced by the addition of isopropylthio- $\beta$-galactoside to a final concentration of $0.1 \mathrm{mM}$, followed by the further incubation at $15^{\circ} \mathrm{C}$ for $20 \mathrm{~h}$. The cells were collected by centrifugation and stored at $-80^{\circ} \mathrm{C}$ until use.

Purification of rOsBEIIb. All the procedures were performed at $0^{\circ} \mathrm{C}$ unless otherwise described. Cells including the recombinant OsBEIIb (rOsBEIIb) protein were suspended in an extraction buffer (50 mM imidazol- $\mathrm{HCl}$ (pH 7.4), 12.5\% glycerol and $50 \mathrm{~mm}$ 2-mercaptoethanol) and lysed by sonification. The crude cell extract was centrifuged twice at $10,000 \times g$ at $0^{\circ} \mathrm{C}$ for $30 \mathrm{~min}$. The supernatant of the crude extract was applied to a HitrapQ HP column (column volume, $10 \mathrm{~mL}$, Amersham Biosciences) equilibrated with the extraction buffer. After the column had been washed with the extraction buffer, the rOsBEIIb protein was eluted with a linear gradient of 0.0 to $0.5 \mathrm{M}$ sodium chloride for $30 \mathrm{~min}$ in the extraction buffer at a flow rate of $2 \mathrm{~mL} / \mathrm{min}$. The fractions containing the rOsBEIIb protein were collected and pooled, and the combined fractions were desalted and concentrated by an Amicon Ultra-4 (Millipore Corporation) membrane filter. Subsequently the concentrated fraction was applied to a TSKgel Ether-5PW hydrophobic column $(75 \times 7.5 \mathrm{~mm}$, Tosoh Corporation) equilibrated with medium A including $50 \mathrm{~mm}$ sodium-phosphate ( $\mathrm{pH} 7.0$ ), $1.0 \mathrm{M}$ ammonium sulfate and $50 \mathrm{~mm}$ 2-mercaptoethanol. The rOsBEIIb protein was eluted with a descendent linear gradient of 1.0 to $0.0 \mathrm{M}$ ammonium sulfate for $30 \mathrm{~min}$ in the medium $\mathrm{A}$ at a flow rate of $1 \mathrm{~mL} / \mathrm{min}$. The peak fractions of the rOsBEIIb protein were collected and concentrated by ultrafiltration as described above, and then the buffer solution of the rOsBEIIb preparation was replaced by $50 \mathrm{~mm}$ imidazol- $\mathrm{HCl}(\mathrm{pH} 7.4), 8 \mathrm{~mm}$ magnesium chloride, $5 \mathrm{~mm}$ dithiothreitol and $12.5 \%(\mathrm{v} / \mathrm{v})$ glycerol. The purified rOsBEIIb preparation was stored at $-80^{\circ} \mathrm{C}$ until use. 
Measurement of $B E$ activity by the BCA assay. The standard reaction mixture for assay of $\mathrm{BE}$ contained $10 \mathrm{~mm}$ potassium-phosphate $(\mathrm{pH} 7.4), 0.40 \mathrm{mg}(3.45 \mu \mathrm{M})$ of AS-1160 or $1.20 \mathrm{mg}$ of ae-amylopectin, and rOsBEIIb $(6.42 \mu \mathrm{g}$ protein) in a total volume of $100 \mu \mathrm{L}$. The reaction was run for $10 \mathrm{~min}$ at $30^{\circ} \mathrm{C}$. After terminating the reaction by treatment of the reaction mixture at $100^{\circ} \mathrm{C}$ for $10 \mathrm{~min}$, the solution was supplemented with $100 \mu \mathrm{L}$ of 0.1 M sodium-acetate $(\mathrm{pH} 3.5)$ containing $0.5 \mathrm{U}$ of isoamylase from Pseudomonas amyloderamosa, and incubated at $37^{\circ} \mathrm{C}$ for $60 \mathrm{~min}$. The debranching treatment was stopped by adding $200 \mu \mathrm{L}$ of $0.1 \mathrm{M}$ sodium hydroxide. An aliquot (10 to $100 \mu \mathrm{L})$ of the resulting solution and distilled water to a final volume of $225 \mu \mathrm{L}$ was mixed with $225 \mu \mathrm{L}$ of the working reagent including Solutions A and B, as described in MAterials AND Methods, although the solution was occasionally diluted with distilled water by appropriate volumes so that absorbance of the resulting assay mixture at $560 \mathrm{~nm}$ was in the permitted range $\left(0^{-} 0.75\right)$ of the BCA assay although $150 \mu \mathrm{L}$ of the assay mixture was used for measuring the absorbance by the microplate spectrophotometer as described above (Fig. 1). After being incubated at $80^{\circ} \mathrm{C}$ for $40 \mathrm{~min}$, the mixture was then cooled on ice and stood for $10 \mathrm{~min}$. The rOsBEIIb activity was calculated from the difference in absorbance of the mixture between incubation at a given time and no incubation.

Measurement of $B E$ activity with the iodine stain assay. The standard reaction mixture and the reaction condition for assay of rOsBEIIb was the same as that used in the BCA method. After the BE reaction was terminated by treatment of the mixture at $100^{\circ} \mathrm{C}$ for $10 \mathrm{~min}, 15 \mu \mathrm{L}$ or $30 \mu \mathrm{L}$ of the reaction mixture containing AS-1160 or ae-amylopectin, respectively, as substrate was supplemented with $300 \mu \mathrm{L}$ of $1 \mathrm{M}$ hydrochloric acid, $150 \mu \mathrm{L}$ of $1 \% \mathrm{I}_{2}-0.1 \% \mathrm{KI}$ and $1535 \mu \mathrm{L}$ of distilled water, and the absorbance of the resulting assay mixture at $660 \mathrm{~nm}\left(\lambda_{\max }\right.$ for AS-1160) or at $560 \mathrm{~nm}$ ( $\lambda$ max for $a e$-amylopectin), respectively, was measured using a spectrophotometer (DU 7400, Beckman Inc.).

\section{RESULTS AND DISCUSSION}

\section{Basic Properties of BCA method.}

The best way to measure the enzymatic activity of starch branching enzyme (BE) is to quantify directly the $\alpha-1,6$-glucosidic linkages of glucan products generated after its enzymatic reaction. The BCA method in the present study and the modified Park-Johnson method established by Hizukuri et al. $(1981)^{28)}$ meet this requirement. Therefore, we compared the basic properties of the two methods. The absorbance at $\lambda_{\max }$ either in the BCA method $(560 \mathrm{~nm})$ or the modified Park-Johnson method $(715 \mathrm{~nm})$ was proportional to the increase of the reducing terminal in range of the 0 to $25 \mu \mathrm{M}$ of glucose in the assay mixture (Fig. 1), and the sensitivity did not change when maltose or maltotriose was used as the standard (data not shown), although the molar absorption coefficients at $\lambda_{\max }$ for the BCA method and the modified Park-Johnson method were determined to be 45,600 (560 nm) and $52,300(715 \mathrm{~nm})$, respectively. The results show that both
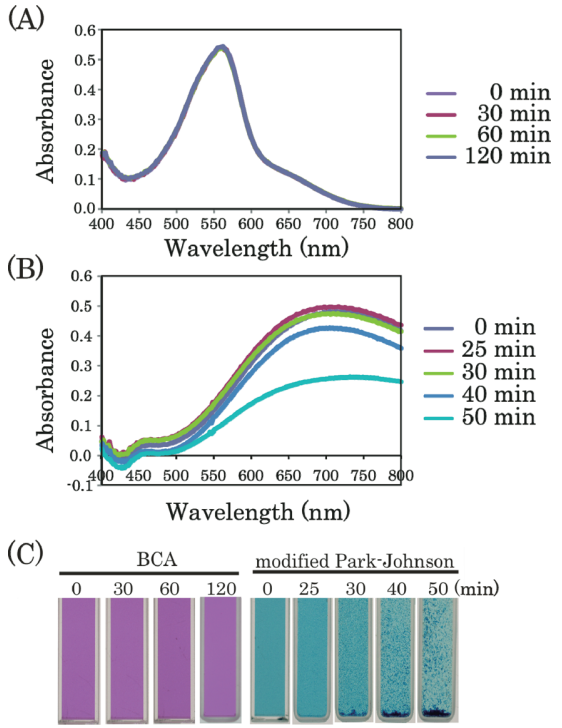

Fig. 2. Color stability of the assay mixture used for the BCA method and the modified Park-Johnson method.

The standard glucose was stained by the BCA method (A) or the modified Park-Johnson method (B) so that the final concentration of glucose was $12.5 \mu \mathrm{M}$ in the assay mixture. Immediately 0,30 , 60 and $120 \mathrm{~min}(\mathrm{~A})$, or $0,25,30,40$ and $50 \mathrm{~min}(\mathrm{~B})$, respectively, after the mixture was visualized, it was transferred to a cuvette (light path, $1 \mathrm{~cm}$ ) and the absorbance spectrum was measured in the range of the wavelength from 400 to $800 \mathrm{~nm}$ using a spectrophotometer (DU 7400, Beckmann). (C) shows the change, if any, in liquid state of the assay mixture appearing in the BCA method (left panel) or the modified Park-Johnson method (right panel) after the visualization of the mixture. It is noted that ferric-ferrocyanide started to aggregate $30 \mathrm{~min}$ after the addition of all the reagents in the modified Park-Johnson method whereas copper-bicinchoninate stayed resolved in the solution within $120 \mathrm{~min}$ in the BCA method, and it continued for at least $10 \mathrm{~h}$ (data not shown).

methods are more sensitive by approximately 20-fold compared with the Somogyi-Nelson method. ${ }^{17,26,27)}$ The absorbance coefficiency of the BCA method was not affected by the presence of $50 \mathrm{mM}$ each of the buffer solution of MOPS-NaOH ( $\mathrm{pH} 7.0)$, HEPES-NaOH ( $\mathrm{pH} 7.4)$, Bicine- $\mathrm{NaOH}(\mathrm{pH} 8.0)$, Na-acetate ( $\mathrm{pH} 5.0)$, potassiumphosphate ( $\mathrm{pH} 7.4)$, Tris- $\mathrm{HCl}(\mathrm{pH} 7.4)$, or imidazole-HCl (pH 7.4), while it was slightly higher in $50 \mathrm{mM}$ MES$\mathrm{NaOH}$ buffer ( $\mathrm{pH}$ 6.0) solution (data not shown). In this study $10 \mathrm{~mm}$ potassium-phosphate $(\mathrm{pH} \mathrm{7.4)}$ was used for assay of rice $\mathrm{BE}$ isozyme.

No changes were observed in the absorption spectrum having a $\lambda_{\max }$ at $560 \mathrm{~nm}$ in the BCA-treated solution for 120 min (Figs. 2 (B) and 2 (C)) or longer up to at least $10 \mathrm{~h}$ (data not shown). By contrast, the solution prepared according to the procedure of the modified Park-Johnson method yielding a broad absorption peak at around $715 \mathrm{~nm}$ gave rise to precipitates about $25 \mathrm{~min}$ after the addition of the modified Park-Johnson reagents, and the amount of the precipitates increased with the increase of the time and therefore the intensity of the absorbance at $715 \mathrm{~nm}$ markedly decreased with time after $30 \mathrm{~min}$ until 50 min (Figs. 2 (B) and 2 (C)). Moreover, the amount of the precipitates was dependent on the buffer solutions used and was enhanced by the addition of 10-50 mM potassium-phosphate in the solution (data not shown). The results indicate that the $\mathrm{BCA}$ method is superior to the modified Park-Johnson method in terms of stability of the 
stained solution, and the BCA method is useful especially when a large number of samples should be measured.

\section{Effects of DP values of linear malto-oligosaccharides and glucans on the intensity of the absorbance in the BCA methods}

The previous report by Hizukiri et al. $(1981)^{28)}$ showed that ferric-ferrocyanide used in the modified Park-Johnson method gives the same reducing power for reducing saccharides such as glucose, malto-oligosaccahrides (MOS) and linear glucans with DP40. In an attempt to examine the relationship between the absorption values and the calculated values in reducing powers of sugars, maltooligosaccahrides and glucans, these reducing powers including glucose, maltose, maltotriose, maltohexaose, and amylose with DP $n$ of 34 (AS-7), 317 (AS-55), 1658 (AS290), 4820 (AS-820) and 6510 (AS-1160), respectively, were determined by both the BCA method and the modified Park-Johnson method (Fig. 3). From the two methods the equivalent values were obtained in the wide range of DP values from 1 to at least 1658 , whereas the estimated values of long glucans with DP $n 4820$ and 6510 were apparently higher than the calculated values. The result shows the possibility that large $M_{\mathrm{w}}$ amyloses with $\mathrm{DP} n$ 4820 and 6510 give higher molar absorption coefficients in both spectrophotometric assays, or that these sample preparations contains smaller $M_{\mathrm{w}}$ constituents although the apparent higher values of these amyloses were not reduced even after these amylose preparations had been purified by repeated precipitation (5 times) with $10 \%(\mathrm{v} / \mathrm{v})$ 1-butanol in the presence of $5 \mathrm{~mm} \mathrm{NaCl}$.

These results indicate that the reducing power of $\alpha$ glucan ranging from DP1 (glucose) up to at least approximately DP $n 1658$ (AS-290) can be correctly estimated by the BCA method, although the measured reducing powers of the longer glucans such as AS-820 (DP $n 4820)$ and AS1160 (DPn6510) were slightly higher than the calculated reducing powers. Based on the results, the BCA method can directly determine the number of $\alpha$-1,6-glucosidic linkages which are formed after the BE enzymatic reac-

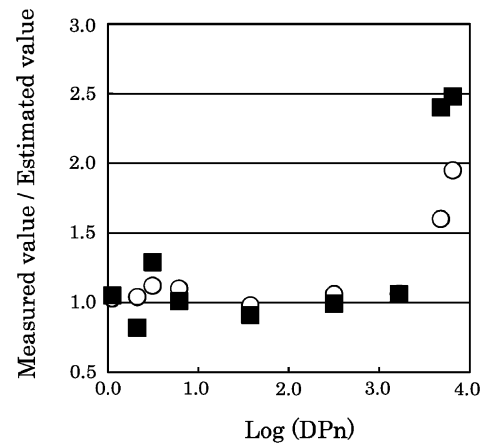

Fig. 3. Relationship between the calculated numbers of reducing terminals of standard sugars, malto-oligosaccharides and amyloses and the estimated values obtained by the BCA method (open circle) or the modified Park-Johnson method (closed square).

The standard samples: glucose (DP1); maltose (DP2); maltotriose (DP3); maltohexaose (DP6); AS-7 (DPn34); AS-55 (DPn317); AS290 (DPn 1658); AS-820 (DPn4820); AS-1160 (DPn6510). The concentration of each standard sample used was $12.5 \mu \mathrm{M}$ in the assay mixture. The values are the averages of at least three triplicate measurements from three independent preparations. tion, and then treated with $P$. amyloderamosa isoamylase by measuring the number of reducing terminals generated in the isoamylorysates as long as chain lengths of newly formed chains including donor (transferred) chains, acceptor chains and residual chains ${ }^{42)}$ produced by BE reactions are in the range of DP1-1658. Since it is known that BEI preferentially transfers the $\alpha$-glucan chains with DP approximately 50,14, 11 and BEII forms preferentially the shorter chains with DP6 and 7,,,$^{1720-23)}$ the BCA method can quantitatively estimate the number of generated chains by $\mathrm{BE}$ reaction under conditions where the glucan chains formed by BE have DP $\leq 1658$.

\section{Characterization of $B E$ assays using amylose and amylopectin as substrate}

Amylose has been mostly used as substrate to characterize plant BE isozymes because average chain lengths of amylopectin are greatly shorter than amylose, and hence the background value of the reaction mixture including amylopectin is too high to estimate the $\alpha$-1,6-glucosidic linkages generated by the BE enzymatic reaction when the concentration of amylopectin used is high.

In this study, both amylose of DPn6510 (AS-1160) and amylopectin prepared from endosperm of a rice BEIIbdeficient ae mutant line EM10 were used to examine whether these substrates are appropriate to characterize recombinant rice BEIIb (rOsBEIIb) by the BCA method,

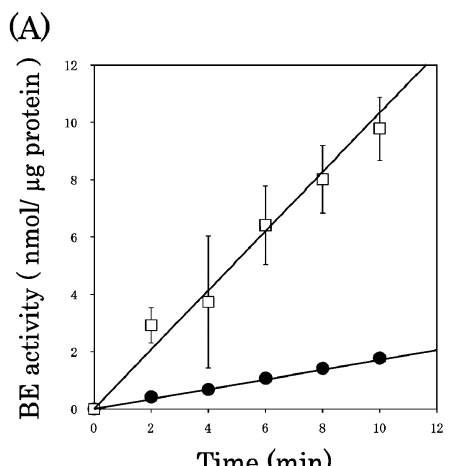

(B)

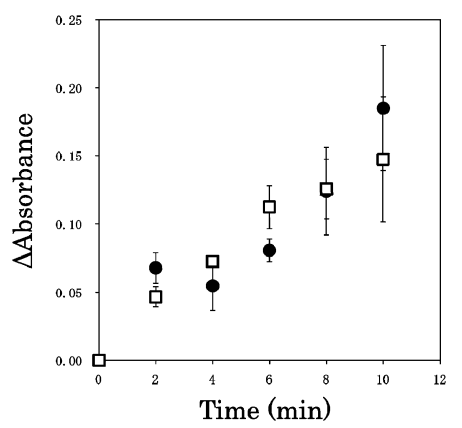

Fig. 4. Time course of the rOsBEIIb reaction.

rOsBEIlb was reacted with $1.20 \mathrm{mg}$ of ae-amylopectin (open square) or $0.40 \mathrm{mg}$ of AS-1160 (closed circle) in $10 \mathrm{~mm}$ potassiumphosphate ( $\mathrm{pH}$ 7.4) in a total volume of $100 \mu \mathrm{L}$ for various periods as shown in the figure, and the $\mathrm{BE}$ activities were calculated according to the BCA method (A) or the iodine stain assay (B). The $\mathrm{BE}$ activity measured by the BCA method was expressed as nmol equivalent $\alpha-1,6$-glucosidic linkage formed/ $\mu \mathrm{g}$ protein in the reaction mixture (A). The means and standard deviations were calculated from triplicate assays from three independent preparations in the BCA method and duplicate assays from two independent preparations in the iodine stain assay. 


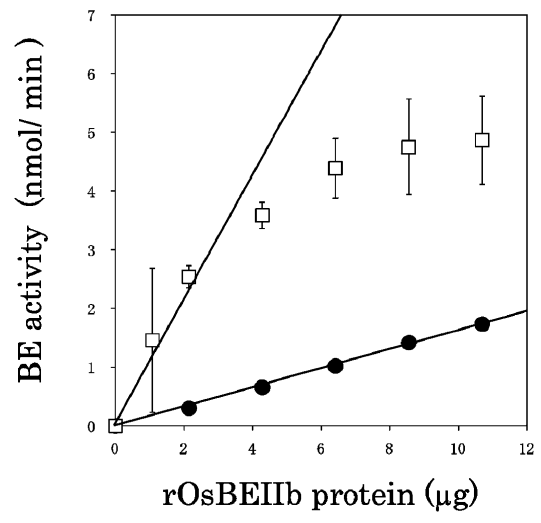

Fig. 5. Relationship between the amount of rOsBEIIb protein and the BE activity measured by the BCA method in $10 \mathrm{mM}$ potassium-phosphate $(\mathrm{pH} 7.4)$ and $1.20 \mathrm{mg}$ of $a e$ amylopectin (open square) or $0.40 \mathrm{mg}$ of AS-1160 (closed circle) in a total volume of $100 \mu \mathrm{L}$ for $10 \mathrm{~min}$.

The BE activity measured by the BCA method was expressed as nmol equivalent $\alpha-1,6$-glucosidic linkage formed/min in the reaction mixture while the amount of rOsBEIIb was expressed as $\mu \mathrm{g}$ protein in the reaction mixture. The means and standard deviations were calculated from duplicate assays from two independent preparations.

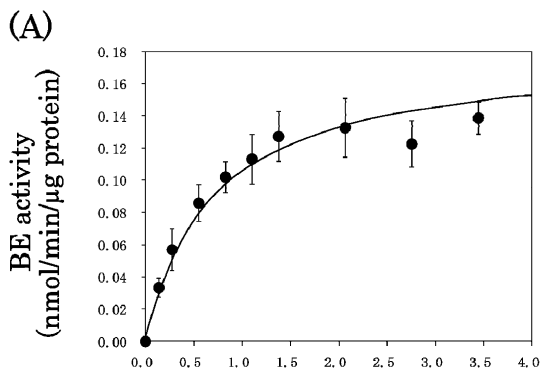

[S] $(\mu \mathrm{M})$

(B)

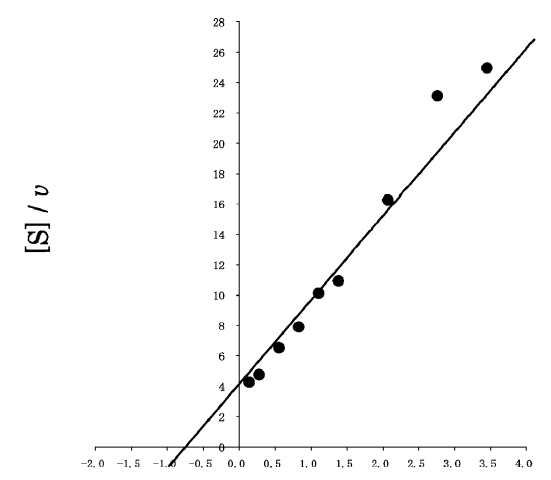

[S] $(\mu \mathrm{M})$

Fig. 6. Kinetic characterization of rOsBEIIb.

(A) The relationship between the BE activity and the substrate [S] concentration of AS-1160. The BE activity measured by the BCA method was expressed as nmol equivalent $\alpha-1,6$-glucosidic linkage formed $/ \mathrm{min} / \mu \mathrm{g}$ protein in the reaction mixture while the concentration of AS-1160 used in the reaction mixture was expressed as $\mu \mathrm{M}$. (B) Plots of $[\mathrm{S}] / v$ versus $[\mathrm{S}]$ with respect to the rOsBEIIb activity toward AS-1160.

and the results were compared with those obtained in the iodine stain assay. ${ }^{24)}$ In the BCA method, the rOsBEIIb activity with $a e$-amylopectin or AS-1160 (DPn6510) linearly proceeded up to $10 \mathrm{~min}$ (Fig. 4 (A)), whereas in the iodine stain assay the rOsBEIIb activity did not show a linear increase with the course of time especially when AS-1160 was used as substrate (Fig. 4 (B)).

Figure 5 shows that the BEIIb activity measured by the BCA assay increased with the increase in the enzyme content within 2 and $10 \mu \mathrm{g} / 100 \mu \mathrm{L}$ of the reaction mixture when rOsBEIIb was reacted either with aeamylopectin or AS-1160, respectively.

Based on all the above results, we tried to obtain the kinetic parameters of rice BEIIb for both $K_{\mathrm{m}}$ and $V_{\max }$ values by changing the substrate (AS-1160) concentrations from 0.14 to $3.45 \mu \mathrm{M}$ (Fig. 6), although it is generally known that the BEIIb-type is less reactive to amylose. ${ }^{19)}$ Under the reaction conditions DP values of most $(>$ at least $95 \%$ ) of the transferred chains were within 100 (data not shown), indicating that number of newly formed branched chains was correctly determined by the BCA assay. From the results we could calculate the $K_{\mathrm{m}}$ value for $0.78 \mu \mathrm{M}$ AS-1160 and the $V_{\max }$ value of $0.19 \mu \mathrm{mol} / \mathrm{mg}$ protein/min.

\section{CONCLUSION}

In previous studies on the assay and properties of $\mathrm{BE}$ isozymes, amylose was usually used as glucan substrate because of its low proportion of reducing terminal per number of glucose moieties, ${ }^{17)}$ whereas amylopectin tends to give rise to higher background in the branched linkage assay method when it has been debranched before the assay. In the other assays such as the iodine stain assay and phosphorylase a-stimulation assay, ${ }^{24)}$ it is very difficult to determine precisely the velocity of BE activity because the activity measured does not necessarily proceed linearly with the elapse of the reaction time. The present paper has established that the BCA method is useful not only to determine the BE enzymatic activity on the molar basis, but also to determine the kinetic parameters even when amylopectin is the substrate, and therefore we can compare these values and parameters between amylopectin and amylose.

\section{REFERENCES}

1 ) K. Kainuma and D. French: Naegeli amylodextrin and its relationship to starch granule structure. II. Role of water in crystallization of B-starch. Biopolymer, 11, 2241-2250 (1972).

2 ) S. Hizukuri: Starch: Analytical aspects. in Carbohydrates in Food, A.C. Eliasson, ed., Marcel Dekker, Inc., New York, pp. 347-428 (1996).

3 ) M.J. Gidley and P.V. Bulpin: Crystallisation of maltooligosaccharides as models of the crystalline forms of starch: minimum chain-length requirement for the formation of double helices. Carbohydr. Res., 161, 291-300 (1987).

4 ) S. Hizukuri: Polymodal distribution of chain lengths of amylopectins, and its significance. Carbohydr. Res., 147, 342-347 (1986).

5 ) D.B. Thompson: On the non-random nature of amylopectin branching. Carbohydr. Polym., 43, 223-239 (2000).

6 ) Y. Nakamura, J. Takahashi, A. Sakurai, Y. Inaba, E. Suzuki, S. Nihei, S. Fujiwara, M. Tsuzuki, H. Miyashita, H. Ikemoto, M. Kawachi, H. Sekiguchi and N. Kurano: Some cyanobacteria synthesize semi-amylopectin type $\alpha$-polyglucans instead of glycogen. Plant Cell Physiol., 46, 539-545 (2005).

7 ) P. Deschamps, C. Colleoni, Y. Nakamura, E. Suzuki, J.L. Putaux, A. Buléon, S. Haebel, G. Ritte, M. Steup, L.I. Falcón, D. 
Moreira, W. Loffelhardt, J.N. Raj, C. Plancke, C. d'Hulst, D. Dauvillée and S. Ball: Metabolic symbiosis and the birth of the plant kingdom. Mol. Biol. Evol., 25, 536-548 (2008).

8 ) Y. Nakamura: Towards a better understanding of the metabolic system for amylopectin biosynthesis in plant: rice endosperm as a model tissue. Plant Cell Physiol., 43, 718-725 (2002).

9 ) S.G. Ball and M.K. Morell: From bacterial glycogen to starch: understanding the biogenesis of the plant starch granule. Annu. Rev. Plant Biol., 54, 207-233 (2003).

10) H. Yamanouchi and Y. Nakamura: Organ specificity of isoforms of starch branching enzyme (Q-enzyme) in rice. Plant Cell Physiol., 33, 985-991 (1992).

11) K. Mizuno, T. Kawasaki, H. Shimada, H. Satoh, E. Kobayashi, S. Okumura, Y. Arai and T. Baba: Alteration of the structural properties of starch components by the lack of an isoform of starch branching enzyme in rice seeds. J. Biol. Chem., 268, 19084-19091 (1993).

12) D.K. Fisher, M. Gao, K.-N. Kim, C.D. Boyer and M.J. Guiltinan: Allelic analysis of the maize amylose-extender locus suggests that independent genes encode starch-branching enzymes IIa and IIb. Plant Physiol., 110, 611-619 (1996).

13) Y. Han, E. Bendik, F. Sun, K. Gasic and S.S. Korban: Genomic isolation of genes encoding starch branching enzyme II (SBEII) in apple: toward characterization of evolutionary disparity in SbeII genes between monocots and eudicots. Planta, 226, 1265-1276 (2007).

14) A. Nishi, Y. Nakamura, N. Tanaka and H. Satoh: Biochemical and genetic analysis of the effects of amylose-extender mutation in rice endosperm. Plant Physiol., 127, 459-472 (2001).

15) H. Satoh, A. Nishi, K. Yamashita, Y. Takemoto, Y. Tanaka, Y. Hosaka, A. Sakurai, N. Fujita and Y. Nakamura: Starchbranching enzyme I-deficient mutation specifically affects the structure and properties of starch in rice endosperm. Plant Physiol., 133, 1111-1121 (2003).

16) C.D. Boyer and J. Preiss: Multiple forms of $(1,4)-\alpha-D-$ glucan, $(1,4)-\alpha$-D-glucan-6-glycosyl transferase from developing Zea mays L. kernels. Carbohydr. Res., 61, 321-334 (1978).

17) Y. Takeda, H.P. Guan and J. Preiss: Branching of amylose by the branching isoenzymes of maize endosperm. Carbohydr. Res., 240, 253-263 (1993).

18) H.P. Guan and J. Preiss: Differentiation of the properties of the branching isozymes from maize (Zea mays). Plant Physiol., 102, 1269-1273 (1993).

19) H.P. Guan, T. Baba and J. Preiss: Expression of branching enzyme I of maize endosperm in Escherichia coli. Plant Physiol., 104, 1449-1453 (1994).

20) H.P. Guan, P. Li, J.I. Radosevich, J. Preiss and P. Keeling: Comparing the properties of Escherichia coli branching enzyme and maize branching enzyme. Arch. Biochem. Biophys., 342, 92-98 (1997).

21) S. Hamada, K. Nozaki, H. Ito, Y. Yoshimoto, H. Yoshida, S. Hiraga, S. Onodera, M. Honma, Y. Takeda and H. Matsui: Two starch-branching-enzyme isoforms occur in different fractions of developing seeds of kidney bean. Biochem. J., 359, 23-34 (2001).

22) K. Mizuno, E. Kobayashi, M. Tachibana, T. Kawasaki, T. Fujimura, K. Funane, M. Kobayashi and T. Baba: Characterization of an isoform of rice starch branching enzyme, RBE4, in developing seeds. Plant Cell Physiol., 42, 349-357 (2001).

23) U. Rydberg, L. Andersson, R. Andersson, P. Åman and H. Larsson: Comparison of starch branching enzyme I and II from potato. Eur. J. Biochem., 268, 6140-6145 (2001).

24) J.S. Hawker, J.L. Ozbun, H. Ozaki, E. Greenberg and J. Preiss: Interaction of spinach leaf adenosine diphosphate glucose $\alpha$ 1,4 glucan $\alpha$-4-glucosyl transferase and $\alpha-1,4$ glucan, $\alpha-1,4$ glucan-6-glycosyl transferase in synthesis of branched $\alpha$ glucan. Arch. Biochem. Biophys., 160, 530-551 (1974).

25) D. Borovsky, E.C. Smith and W.J. Whelan: Purification and properties of potato 1,4- $\alpha$-D-glucan: $6-\alpha-(1,4-\alpha-$-glucano)transferase: evidence against a dual catalytic function in amylose-branching enzyme. Eur. J. Biochem., 59, 615-625 (1975).

26) N. Nelson: A photometric adaptation of the Somogyi method for the determination of glucose. J. Biol. Chem., 153, 375-380
(1944).

27) M. Somogyi: Notes on sugar determination. J. Biol. Chem., 195, 19-23 (1952).

28) S. Hizukuri, Y. Takeda and M. Yasuda: Multi-branched nature of amylose and the action of debranching enzymes. Carbohydr. Res., 94, 205-213 (1981).

29) I. Hanashiro, H. Shinohara and Y. Takeda: Application of fluorescent labeling/HPSEC method to structural characterization of the product from amylose by starch branching enzyme. J. Appl. Glycosci., 50, 487-491 (2003).

30) E.M. Gindler: Nomogram for calculation of concentration for colorimetric systems in which absorbance decreases linearly as concentration increases. Clin. Chem., 16, 350-351 (1970).

31) S. Waffenschmidt and L. Jaenicke: Assay of reducing sugars in the nanomole range with 2,2'-bicinchoninate. Anal. Biochem., 165, 337-340 (1987).

32) J.D. Fox and J.F. Robyt: Miniaturization of three carbohydrate analyses using a microsample plate reader. Anal. Biochem., 195, 93-96 (1991).

33) L.W. Doner and P.L. Irwin: Assay of reducing end-groups in oligosaccharide homologues with 2,2'-bicinchoninate. Anal. Biochem., 202, 50-53 (1992).

34) P.J.A. Meeuwsen, J-P. Vincken, G. Beldman and A.G.J. Voragen: A universal assay for screening expression libraries for carbohydrases. J. Biosci. Bioenginer., 89, 107-109 (2000).

35) H. Hussain, A. Mant, R. Seale, S. Zeeman, E. Hinchliffe, A. Edwards, C. Hylton, S. Bornemann, A.M. Smith, C. Martin and R. Bustos: Three isoforms of isoamylase contribute different catalytic properties for the debranching of potato glucans. Plant Cell, 15, 133-149 (2003).

36) Y. Utsumi and Y. Nakamura: Structural and enzymatic characterization of the isoamylase 1 homo-oligomer and the isoamylase1-isoamylase2 hetero-oligomer from rice endosperm. Planta, 225, 75-87 (2006).

37) D.B. Johnston, S.P. Shoemaker, G.M. Smith and J.R. Whitaker: Kineteic measurements of cellulase activity on insoluble substratesusing disodium 2,2' bicinchoninate. J. Food. Biochem., 22, 301-319 (1998).

38) S. Kitamura, H. Yunokawa, S. Mitsuie and T. Kuge: Study on polysaccharides by the fluorescence method. II. MicroBrownian motion and conformational change of amylose in aqueous solution. Polym. J., 14, 93-99 (1982).

39) S. Kitamura, K. Kobayashi, H. Tanahashi, T. Ozeki and T. Kuge: On the Mark-Houwink-Sakurada equation for amylose in aqueous solvents. J. Jpn. Soc. Starch Sci., 36, 257-264 (1989).

40) Y. Nakanishi, T. Norisuye, A. Teramoto and S. Kitamura: Conformation of amylose in dimethyl-sulfoxide. Macromolecules., 26, 4220-4225 (1993).

41) Y. Takeda, S. Hizukuri and B.O. Juliano: Purification and structure of amylose from rice starch. Carbohydr. Res., 148, 299-308 (1986).

42) D. Borovsky, E.E. Smith and W.J. Whelan: On the mechanism of amylose branching by potato Q-enzyme. Eur. J. Biochem., 16, 307-312 (1976). 


\section{ビシンコニニック酸でグルカンの還元末端数を}

\section{測定することによってデンプン枝作り酵素の活性を}

\section{定量的に測定する方法}

内海好規 ${ }^{1}$, 吉田真由美 ${ }^{1}$, Perigio B. Francisco, Jr. ${ }^{1}$,

澤田隆行 ${ }^{1}$, 北村進一 ${ }^{2}$, 中村保典 ${ }^{1}$

${ }^{1}$ 秋田県立大学生物資源科学部

(010-0195 秋田市下新城中野字街道端西 241-438)

2 大阪府立大学大学院生命環境科学研究科

(599-8531 堺市学園町 1-1)

植物はデンプンを合成するために進化の過程で異なる 機能を持つ酵素アイソザイムを分化させてきた。デンプ ン枝作り酵素 (BE) は $\alpha$-グルカンの $\alpha-1,6$ グルコシド結 合を形成する唯一の酵素であり，アミロペクチンのタン デムクラスター構造の形成に必須である。アミロペクチ ン分子の分岐結合の位置と数に認められる高度の規則性 は BE 反応により制御されており, アミロペクチン構造の バリエーションはデンプンの性質を決定する重要な因子 である。したがってデンプン構造の生合成調節メカニズ ムを解明する上で BE の特性に関する理解は不可欠である が， BE の反応メカニズムは依然ほとんど不明である。 BE 特性解明の第一歩は酵素動力学的解析であるが, 再現性 良く活性を定量し，しかも多数のサンプルを簡便に分析 できる方法がなかった．本研究では，BE 枝作り反応の結 果, 生ずる $\alpha-1,6$ グルコシド結合を枝切り処理後, 増加す る還元末端数を定量することによって活性を直接測定す る方法を確立することを目的とした。まず，還元末端数 を定量できる銅ービシンコニニック酸法 (BCA 法) の基本 特性を調べた。その結果，1) BCA 法では，560 $\mathrm{nm}$ の吸 光度をマイクロプレートリーダーで測定することにより, 測定液 $150 \mu \mathrm{L}$ あたり 0-3.75 nmol (0-25 $\mu \mathrm{M}$ 相当) のマル トースを定量することができ, その吸光度は呈色反応終 了後 10 時間まで安定であった。 2 ) グルコースからグル コース数平均重合度 (DPn) 1658 の酵素合成アミロースに 対して, 分子数あたりの還元糖量は一定で, DP 值の影響 を受けなかった. 3 ) 大腸菌に発現させたイネリコンビ ナント BEIIb (rOsBEIIb) の活性と特性を調べた結果, 酵 素合成アミロースやアミロペクチンに対して信頼性の高 い $K_{\mathrm{m}}$ 值や $V_{\max }$ 值を求めることができた。結論として, BCA 法は従来法に比べて, BE 活性を定量するための優 れた方法であることが明らかになった。 